\title{
Fungicide Sensitivity of U.S. Genotypes of Phytophthora infestans to Six Oomycete-Targeted Compounds
}

Amanda Saville, Department of Plant Pathology, North Carolina State University, Raleigh 27695; Kim Graham, Horticultural Crops Research Laboratory, United States Department of Agriculture-Agricultural Research Service (USDA-ARS), Corvallis, OR; Niklaus J. Grünwald, Horticultural Crops Research Laboratory, USDA-ARS; Department of Botany and Plant Pathology and Center for Genome Biology and Biocomputing, Oregon State University; Kevin Myers and William E. Fry, Department of Plant Pathology and Plant-Microbe Biology, Cornell University; and Jean Beagle Ristaino, Department of Plant Pathology, North Carolina State University

\begin{abstract}
Saville, A., Graham, K., Grünwald, N. J., Myers, K., Fry, W. E., and Ristaino, J. B. 2015. Fungicide sensitivity of U.S. genotypes of Phytophthora infestans to six oomycete-targeted compounds. Plant Dis. 99:659-666.

Phytophthora infestans causes potato late blight, an important and costly disease of potato and tomato crops. Seven clonal lineages of $P$. infestans identified recently in the United States were tested for baseline sensitivity to six oomycete-targeted fungicides. A subset of the dominant lineages $(n=45)$ collected between 2004 and 2012 was tested in vitro on media amended with a range of concentrations of either azoxystrobin, cyazofamid, cymoxanil, fluopicolide, mandipropamid, or mefenoxam. Doseresponse curves and values for the effective concentration at which

$50 \%$ of growth was suppressed were calculated for each isolate. The US- 8 and US-11 clonal lineages were insensitive to mefenoxam while the US-20, US-21, US-22, US-23, and US-24 clonal lineages were sensitive to mefenoxam. Insensitivity to azoxystrobin, cyazofamid, cymoxanil, fluopicolide, or mandipropamid was not detected within any lineage. Thus, current U.S. populations of $P$. infestans remained sensitive to mefenoxam during the displacement of the US-22 lineage by US-23 over the past 5 years.
\end{abstract}

The oomycete plant pathogen Phytophthora infestans (Mont.) de Bary, causal agent of potato late blight, is one of the most economically costly pathogens affecting potato and tomato crops, and is responsible for significant reductions in crop yields both in the US and globally (Anderson et al. 2004). Historically, potato late blight is most notable as the disease that caused the Irish potato famine of the 1840s and resulted in loss of life as well as mass emigration of over two million Irish people (Bourke 1964; Martin et al. 2013). Aggressive new lineages have emerged in recent years and exacerbated disease management (Cooke et al. 2012; Danies et al. 2013; Hu et al. 2012; Kato et al. 1997; Lees et al. 2012)

Fungicides such as Bordeaux mixture were introduced shortly after initial outbreaks for disease control in the 19th century (Turner 2005). In 1979, the phenylamide fungicide metalaxyl (Ridomil) was introduced in Europe for the control of P. infestans; however, within 1 year, insensitive isolates were detected in Ireland (Dowley and O'Sullivan 1981), The Netherlands (Davidse et al. 1981), and elsewhere in other species (Gisi et al. 2011; Hu et al. 2010; Parra and Ristaino 1998). P. infestans was controlled with metalaxyl in the United States during the 1970s and early 1980s because the metalaxyl-sensitive US-1 clonal lineage was the dominant lineage (Goodwin et al. 1994). However, in 1989, outbreaks of $P$. infestans that did not respond to metalaxyl began appearing in the United States, reaching epidemic proportions in the 1990s, resulting in economic losses of hundreds of millions of dollars (Daayf and Platt 2002; Deahl et al. 1993; Goodwin et al. 1998). The introduction in the mid-1990s of mefenoxan, a formulation consisting solely of its

This project was supported with funding from Agriculture and Food Research Initiative Competitive Grants Program Grant 2011-68004-30154.

Corresponding author: J. B. Ristaino; E-mail: Jean_Ristaino@ncsu.edu

*The $\boldsymbol{e}$-Xtra logo stands for "electronic extra" and indicates that one supplementary figure and one supplementary table are published online.

Accepted for publication 3 November 2014.

http://dx.doi.org/10.1094/PDIS-05-14-0452-RE

(c) 2015 The American Phytopathological Society active enantiomer allowed for smaller doses of fungicide to be applied but was not effective in treating metalaxyl-insensitive lineages (Fry et al. 2013; Nuninger et al. 1996). The new outbreaks were caused by several new clonal lineages, including US-6, US-7, and US-8, which were insensitive to metalaxyl. It is believed that these new lineages migrated from Mexico in the 1990s (Goodwin et al. 1998). Metalaxyl had been used in Mexico since the early 1980s, and insensitive isolates are present there (Grünwald et al. 2001; Matuszak et al. 1994; Sujkowski et al. 1995). Over the course of the next few years, the presence of these metalaxyl-insensitive lineages resulted in the displacement of US-1 from the United States and, subsequently, the dominance of the US-8 lineage that infects potato (Goodwin et al. 1998).

In 2009, a severe late blight pandemic occurred in the northeastern United States (Fry et al. 2013; Hu et al. 2012). A combination of favorable weather, widespread dissemination of infected tomato plants through retail stores, and a lack of public knowledge about the symptoms of late blight resulted in crop losses for home gardeners and organic farmers. It was not until the epidemic was well under way that it was determined that most of the outbreaks were caused by a new clonal lineage of $P$. infestans, named US-22 and that this lineage was sensitive to mefenoxam (Fry et al. 2013; Hu et al. 2012). Two additional new lineages, US-23 that infects both tomato and potato and US-24, primarily a potato lineage, were subsequently identified ( $\mathrm{Hu}$ et al. 2012). The 2009 epidemic resulted in efforts to provide better communication between extension agents, researchers, growers, and the general public, and the late blight tracking and alert system USAblight (http://www.usablight. org) was launched. USAblight allows growers to submit reports and samples to affiliated research labs for genotyping and subsequent fungicide testing. In addition to creating communication avenues, the epidemic spurred efforts to better monitor and track relationships between phenotypes (e.g., fungicide sensitivity) and genotypes of current U.S. lineages.

The need for new oomycete-targeted fungicides to control outbreaks of $P$. infestans has resulted in the development of several new chemicals with varying modes of action (Gisi and Sierotzki 2008; Gisi et al. 2012; Mitani et al. 2001; Sauter 2012; Toquin et al. 2012). In addition to mefenoxam, the fungicides azoxystrobin, cymoxanil, cyazofamid, and mandipropamid are all site-specific fungicides and, as a result, are at a greater risk for resistance 
development (Gisi et al. 2011). Shifts in fungicide sensitivity of $P$. infestans within fields in Mexico has been reported but populations were sensitive to all compounds tested but metalaxyl (Grünwald et al. 2006). The baseline sensitivity of current U.S. clonal lineages of $P$. infestans to other oomycete-targeted fungicides needs to be determined.

Collection of isolates of $P$. infestans via USAblight provided an opportunity to generate a baseline of the current fungicide sensitivity of the major lineages. Knowledge of the dominant lineage in a given area and its fungicide sensitivity can result in more informeddecisions on fungicide management. For example, if US-22 was determined to be sensitive to mefenoxam shortly after it was identified, that information could have been used to target fungicides in the 2009 epidemic (Fry et al. 2013; Hu et al. 2012). Although current management practices help to reduce fungicide selection pressure on extant lineages, continued monitoring of fungicide sensitivity through in vitro assays will provide an early warning if a particular lineage develops resistance to a fungicide. The objectives of this study were to establish the baseline fungicide sensitivity of current U.S. clonal lineages of $P$. infestans to oomycete-targeted fungicides and examine changes in the fungicide sensitivity of the clonal lineages over time.

\section{Materials and Methods}

Samples collected From USAblight. Reports of late blight were submitted to the late blight tracking and alert system, USAblight (http://www.usablight.org) in $2011(n=174), 2012(n=312)$, and 2013 ( $n=194)$. A subset of samples from these occurrences were submitted as infected leaves, fruit, or tubers for isolation and genotypic analysis, and tested for fungicide sensitivity.

Study locations. Fungicides were tested at North Carolina State University (NCSU) in Raleigh (mefenoxam, fluopicolide, and cyazofamid), and the United States Department of Agriculture-Agricultural Research Service (USDA-ARS) Horticultural Crops Research Laboratory in Corvallis, OR (USDA-ARS; cymoxanil, azoxystrobin, and mandipropamid). Microsatellite genotyping and mefenoxam sensitivity at two fungicide concentrations of a larger number of isolates collected via USAblight were performed at Cornell University (CU) in Ithaca, NY.

Fungicide sensitivity assay. $P$. infestans samples from the United States and Canada were sent to the Fry lab at Cornell University for genotyping using multiplex microsatellite protocols (Danies et al. 2013; $\mathrm{Li}$ et al. 2013). Isolates collected from these samples were used for subsequent fungicide testing. Isolates that included representative clonal lineages present in the United States from 2004 to $2010(n=19), 2011(n=16)$, and $2012(n=10)$ were collected from either potato or tomato and were used in subsequent experiments (Supplementary Table S1). The lineages included US-8 $(n=7)$, US-11 $(n=8), \operatorname{US}-22(n=6), \operatorname{US}-23(n=13)$, and US-24 $(n=7)$. Isolates of the rare lineages US-20 $(n=2)$ and US-21 $(n=2)$, which have not been found in the United States since 2007, were also included, in addition to several variants of US-11 and US-23 (Danies et al. 2013). Variants were defined as isolates that deviated from published SSR profiles for two or more loci.

Six fungicides, including mefenoxam (Ridomil Gold SL, $45.3 \%$ a.i.; Syngenta), fluopicolide ( $99.1 \%$ a.i.; Valent), cyazofamid (Ranman, $34.5 \%$ a.i.; FMC), cymoxanil (Curzate 60DF, $60 \%$ a.i.; DuPont), azoxystrobin (Abound Flowable, $22.9 \%$ a.i.; Syngenta), and mandipropamid (Revus, $23.3 \%$ a.i.; Syngenta) were used to test baseline sensitivity of the isolates. Stock solutions of the active ingredient (mefenoxam, fluopicolide, cyazofamid, cymoxanil, azoxystrobin, and mandipropamid) at $10^{4} \mu \mathrm{g} \mathrm{ml}^{-1}$ were made by dissolving fungicides in either sterile distilled water (mefenoxam, cyazofamid, cymoxanil, azoxystrobin, and mandipropamid) or sterile dimethyl sulfoxide (fluopicolide).

Fungicide sensitivity assay experiments. Isolates were grown on either nonamended rye-V8 media (NCSU) or nonamended pea agar media (USDA-ARS). Fungicides were added to media to obtain a range of concentrations, as follows: cyazofamid and mefenoxam:
$0,0.1,1,10,100$, and $1,000 \mu \mathrm{g} \mathrm{ml}^{-1}$; fluopicolide: $0,0.1,0.5,1$, and $10 \mu \mathrm{g} \mathrm{ml}^{-1}$; cymoxanil: $0,0.01,0.1,1,10$, and $100 \mu \mathrm{g} \mathrm{ml}^{-1}$; azoxystrobin: $0,0.01,0.05,0.1,1,10$, and $100 \mu \mathrm{g} \mathrm{ml}^{-1}$; and mandipropamid: 0, 0.001, 0.01, 0.025, 0.05, 0.1, and $1 \mu \mathrm{g} \mathrm{ml}^{-1}$. Fungicides were added into media via dilution of stock solutions and the agar was mixed thoroughly before pouring into plates.

A single agar plug ( 3 to $5 \mathrm{~mm}$ ) was removed from actively growing mycelia and placed in the center of each petri plate. Three plates were used for each isolate at each fungicide concentration at NCSU, and two plates were used at USDA-ARS. All plates of a single fungicide and concentration were placed in plastic boxes for incubation. Plates were incubated at $18^{\circ} \mathrm{C}$ in the dark for 1 to 2 weeks. Two independent trials were run for each fungicide. Two perpendicular measurements were made of each colony and the average colony diameter was determined. The growth ( $\mathrm{mm})$ at each fungicide dose was plotted and the effective concentration at which $50 \%$ of growth was suppressed $\left(\mathrm{EC}_{50}\right)$ for a given fungicide was determined.

Analyses were performed using the $\mathrm{R}$ platform for each isolate and fungicide (R Core Team 2012). The R package drc (Ritz and Streibig $2005)$ was used for generating dose-response curves and $\mathrm{EC}_{50}$ values. A log-logistic model was used to generate each dose-response curve for each isolate-fungicide combination. A three-parameter model was used if an isolate showed no growth at the highest concentration of a given fungicide (with the assumption that the lower limits of the data are 0) and a four-parameter model was used if an isolate exhibited growth at the highest concentration. Plots of the growth versus dose were made and the $\mathrm{EC}_{50}$ values were calculated for each isolate and fungicide (Gisi et al. 2011; Mitani et al. 2001; Rekanović et al. 2012). A one-way analysis of variance was performed using a randomized design in $\mathrm{R}$. Differences in mean $\mathrm{EC}_{50}$ between lineages within fungicides were tested using Duncan's multiple range test using the R package agricolae (De Mendiburu 2009). In addition, the relative growth of each isolate on mefenoxam-amended media compared with the unamended control was calculated.

\section{Results}

Changes in clonal lineages over time. A displacement of clonal lineages of $P$. infestans was detected from 2009 to 2013 in the United States (Fig. 1). In 2009, the US-22 lineage was the dominant lineage on tomato (81\%) and US-8, US-22, US-23, and US-24 were present on potato (Fry et al. 2013; Hu et al. 2012). The US-22 lineage decreased in frequency of occurrence on tomato over time and was displaced by the US-23 lineage, which causes disease on both potato and tomato (Fig. 1). In 2009, isolates identified as US-23 made up $17 \%$ of the isolates collected from potato and $16.2 \%$ of isolates collected from tomato. By 2013, $88.2 \%$ of isolates collected from potato and $95.5 \%$ of isolates collected from tomato were the US-23 clonal lineage. The US-24 lineage, a predominantly potato lineage, was first observed in 2009 and increased in 2010 but has declined in frequency of occurrence and was rarely found in 2013. The US-8 clonal lineage, common on potato for many years, decreased in frequency over time and was also rarely found in 2013 .

Isolates of the US-8 and US-11 clonal lineages were insensitive to mefenoxam (Figs. 2 and 3; Table 1). The mean $\mathrm{EC}_{50}$ value of the US-8 isolates collected from potato was $51.4 \mu \mathrm{g} \mathrm{ml}^{-1}$ (range of 1.00 to $103.11 \mu \mathrm{g} \mathrm{ml}^{-1}$ ). The relative growth of the US-8 lineage was greater than $60 \%$ compared with the nonamended control at concentrations up to $10 \mu \mathrm{g} \mathrm{ml}^{-1}$ (Fig. 3). Isolates of the US-8 lineage had lower $\mathrm{EC}_{50}$ values than isolates of the US-11 lineage (Table 1). Insensitivity to mefenoxam varied among US-8 lineages and two isolates had $\mathrm{EC}_{50}$ values of $5 \mu \mathrm{g} \mathrm{ml}^{-1}$ or less. Isolates of the US-11 lineage mostly from tomato had high mean $\mathrm{EC}_{50}$ values of $338.8 \mu \mathrm{g} \mathrm{ml}^{-1}$ (range of 169.88 to $677.15 \mu \mathrm{g} \mathrm{ml}^{-1}$ ). Mean $\mathrm{EC}_{50}$ values for US-11 isolates exposed to mefenoxam were significantly higher than for all other lineages (Table 1). Average percent growth compared with the nonamended control over a range of mefenoxam concentrations was near $100 \%$ at concentrations up to $100 \mu \mathrm{g} \mathrm{ml}^{-1}$ for the US-11 lineage (Fig. 3). Mean $\mathrm{EC}_{50}$ values were less than $5 \mu \mathrm{g} \mathrm{ml}^{-1}$ for the other clonal lineages 
tested. Only US-24 had a mean $\mathrm{EC}_{50}$ value greater than $1 \mu \mathrm{g} \mathrm{ml}^{-1}$ (Table 1). Dose-response curves for these lineages typically displayed a sharp decrease in growth with increasing dose, and little to no growth was observed at the highest mefenoxam concentrations (Fig. 2). Similarly, relative growth of all other lineages decreased with increasing concentrations of mefenoxam and dropped below $50 \%$ of the nonamended control at concentrations higher than $1 \mu \mathrm{g} \mathrm{ml}^{-1}$ (Fig. 3). All isolates of the US-23 clonal lineage had $\mathrm{EC}_{50}$ values less than $5 \mu \mathrm{g} \mathrm{ml}^{-1}$. Three isolates (all clonal lineage US-23) had mean $\mathrm{EC}_{50}$ values of $<0.01$.

Sensitivity to other oomycete-targeted compounds. No isolates of any clonal lineage were insensitive to azoxystrobin, cymoxanil, fluopicolide, mandipropamid, or cyazofamid (Fig. 4). Most isolates of $P$. infestans did not grow on media amended with cyazofamid, and a sharp decline in growth was observed at all concentrations above $0.1 \mu \mathrm{g} \mathrm{ml}^{-1}$ (Supplementary Fig. S1). The only exception was a US-8 lineage isolate collected in $2010\left(\mathrm{NY}-48, \mathrm{EC}_{50}=0.30\right)$. In general, $\mathrm{EC}_{50}$ values for the other oomycete fungicides tested among all isolates were less than $1 \mu \mathrm{g} \mathrm{ml}^{-1}$, with two exceptions (isolate NH-47 and CA-12-2 to cymoxanil in 2011 and 2012, respectively). The US- 8 clonal lineage had the highest average $\mathrm{EC}_{50}$ value for both azoxystrobin $\left(0.08 \mu \mathrm{g} \mathrm{ml}^{-1}\right)$ and fluopicolide $\left(0.47 \mu \mathrm{g} \mathrm{ml}^{-1}\right)$ (Table 2). US-11 had the highest average $\mathrm{EC}_{50}$ value for cymoxanil $\left(0.47 \mu \mathrm{g} \mathrm{ml}^{-1}\right)$, while US-20 had the highest average $\mathrm{EC}_{50}$ value for mandipropamid $\left(0.03 \mu \mathrm{g} \mathrm{ml}^{-1}\right)$. No significant differences in mean $\mathrm{EC}_{50}$ values were observed between any lineages to azoxystrobin and cymoxanil (Table 2). However, there were statistically small differences in mean $\mathrm{EC}_{50}$ values among lineages to fluopicolide and mandipropamid.

\section{Discussion}

The primary goal of this study was to evaluate the baseline sensitivity of recent U.S. genotypes of $P$. infestans to oomycete-targeted fungicides. Insensitivity to mefenoxam was observed among the lineages tested. The US- 8 and US-11 clonal lineages were mefenoxam insensitive and some isolates of these lineages had $\mathrm{EC}_{50}$ values greater than $100 \mu \mathrm{g} \mathrm{ml}^{-1}$. Isolates of the other clonal lineages were sensitive to mefenoxam and had $\mathrm{EC}_{50}$ values less than $10 \mu \mathrm{g} \mathrm{ml}^{-1}$. Mefenoxam insensitivity has been observed in a few isolates of the US-23 and US-24 lineages from a broader sampling of USAblight collected isolates but at very low frequencies (data not shown). These insensitive isolates may have acquired "induced" resistance through exposure to mefenoxam (Childers et al. 2014; Dowley and O'Sullivan 1981). The US-11 clonal lineage had significantly higher $\mathrm{EC}_{50}$ values compared with other lineages on mefenoxam-amended media.

The US-8 lineage has persisted in the United States since the early 1990s, despite the disappearance of other mefenoxam-insensitive genotypes. This may have been the result not only of insensitivity to mefenoxam but also to an increased overall fitness of the US- 8 lineage when compared with other lineages present at the time (Kato et al. 1997). However, this lineage has clearly been displaced since 2009 by more fit lineages on potato such as US-23 and US-24 in recent times (Danies et al. 2013; Hu et al. 2012). Lineages with increased fitness traits such as aggressiveness and resistance to host defenses have been observed displacing less fit genotypes in Europe (Cooke et al. 2012; Day and Shattock 1997; Daggett et al. 1993; Shattock 1988). A similar phenomenon has occurred in the United States in the past; for example, the displacement of the US-1 clonal lineage by novel genotypes (Fry et al. 2013; Goodwin et al. 1998;

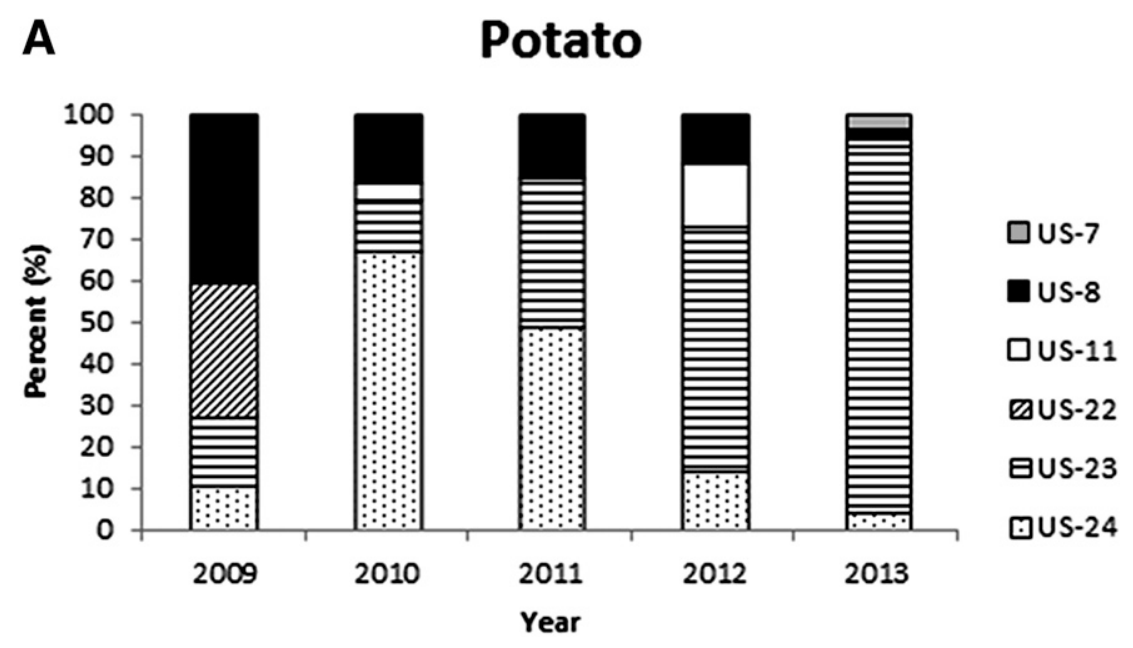

B Tomato

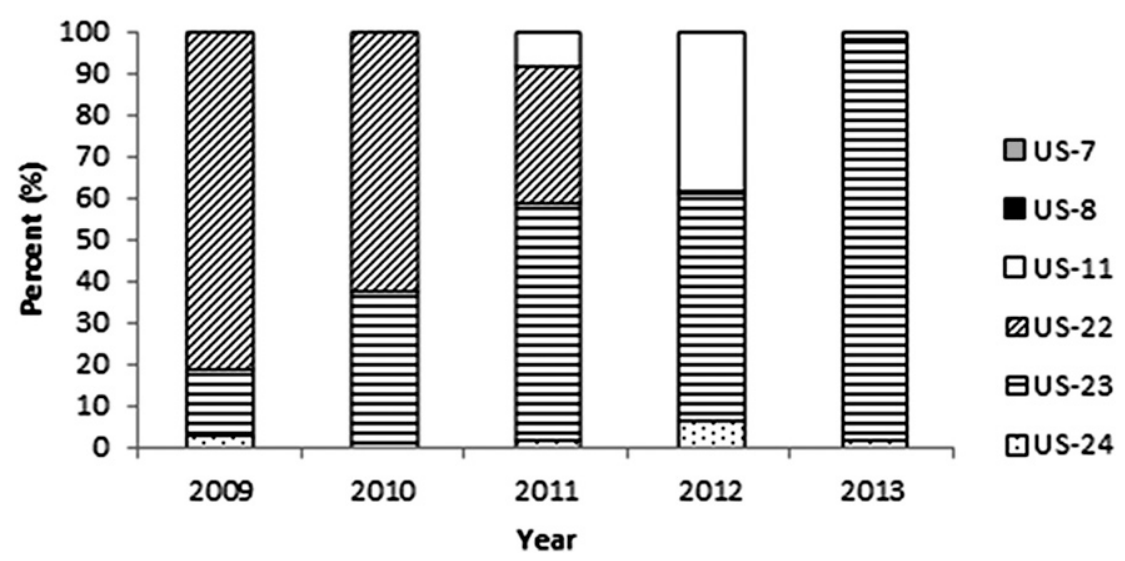

Fig. 1. Frequencies of U.S. lineages of Phytophthora infestans found on A, potato and B, tomato between 2009 and 2013. Data from 2011 to 2013 from USAblight.org. 
Hu et al. 2012). A clear shift in clonal lineages in the United States has occurred as US-22 has been displaced by the widespread US23 that infects both potato and tomato. US-11 reappeared on tomato in 2011 and potato and tomato in 2012. It was first collected in 1994, and has been previously theorized to be a recombinant of A1 mating type lineage US- 6 and either US- 7 or US-8, both A2 lineages that were present at the same time as US-6 (Gavino et al. 2000; Goodwin et al. 1998). US-11 is a common lineage in Taiwan and this mefenoxam-insensitive lineage is thought to have been imported into that country on potato from the Pacific Northwest (Chen et al. 2009).

Based on in vitro studies, there is no evidence of insensitivity among any of the other clonal lineages of $P$. infestans to the other five oomycete-targeted fungicides. $\mathrm{EC}_{50}$ values for all isolates tested on azoxystrobin, cyazofamid, cymoxanil, fluopicolide, and mandipropamid were less than $5 \mu \mathrm{g} \mathrm{ml}{ }^{-1}$. No changes in
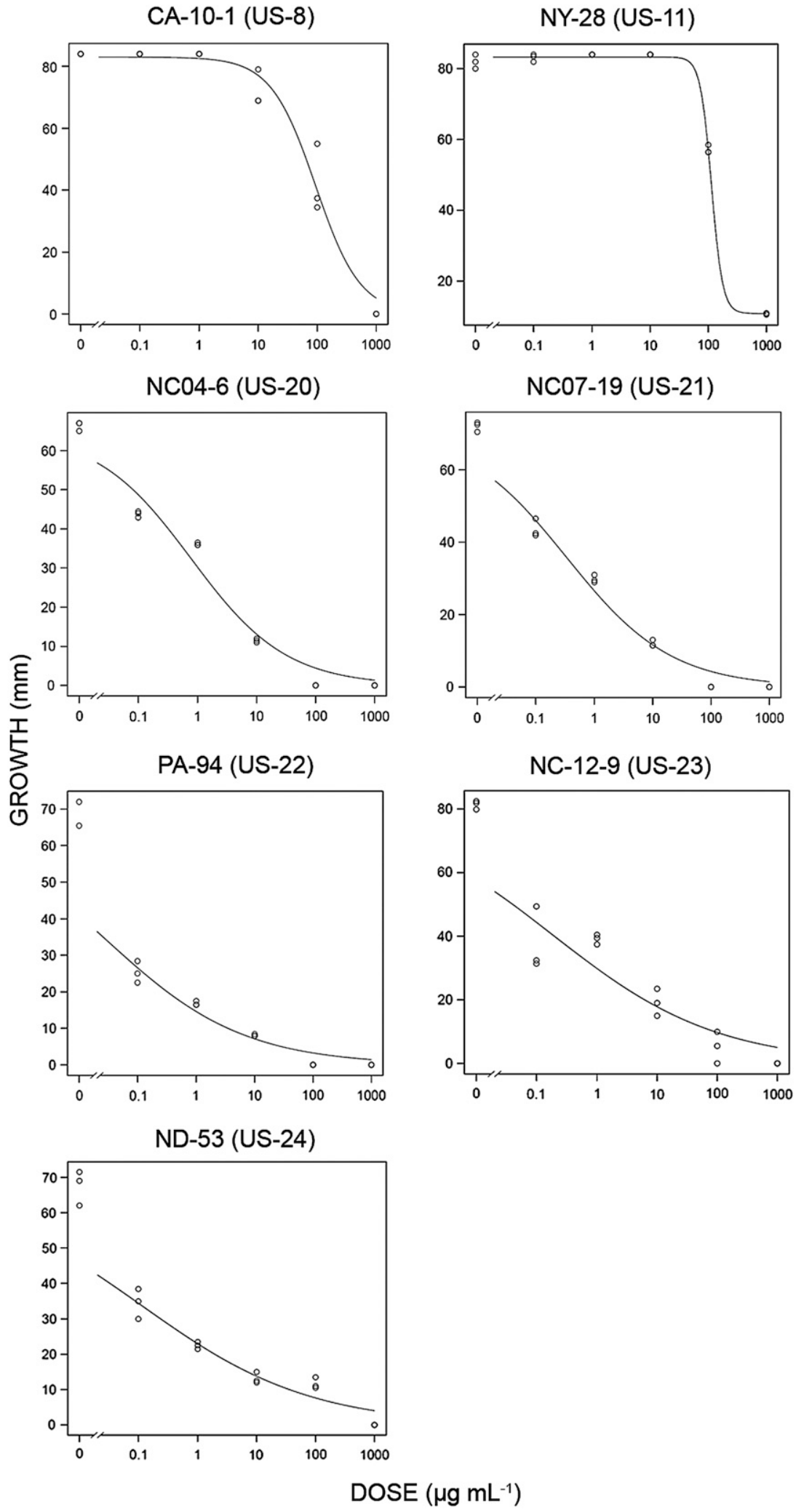

Fig. 2. Dose-response curves for growth of a typical US-8, US-11, US-20, US-21, US-22, US-23, and US-24 clonal lineage of Phytophthora infestans to mefenoxam. 
sensitivity in samples collected in different years (2009 to 2012) to any of these fungicides were observed among the clonal lineages tested.

The lack of insensitivity within lineages to the other five fungicides tested may be due, in part, to good fungicide management plans in the field and the less frequent use of some of these site-specific compounds for control of $P$. infestans. With the exception of cymoxanil, all fungicides in this study were released during or after the midto late 1990 s, after the emergence of mefenoxam-insensitive strains. When considered in combination with the prevalence of good management practices, such as combining site-specific with multisite fungicides (Ojiambo et al. 2010), it is possible that selection pressure for these fungicides may be low enough that they remain sensitive and selection has not occurred in the current populations. Although some of the fungicides tested are site specific, which could increase the chance of resistance development, other factors may be at work to prevent the development of resistant genotypes. For example, attempts to generate artificial mutants of $P$. infestans resistant to the site-specific fungicide mandipropamid have been unsuccessful, with possible reasons cited being an inability to induce mutation, a requirement for multilocus mutations, the poor fitness of mutants, or the rarity of oospores (Rubin et al. 2008). Cymoxanil, despite being introduced over 40 years ago, has persisted as an effective fungicide. Outside of the United States, some studies have detected a shift in sensitivity to cymoxanil in P. infestans (Grünwald et al. 2006) but others have not (Pérez et al. 2009). Although the mode of action for cymoxanil is unknown, its persistent effectiveness may be due, in part, to its use as a preventative treatment rather than a curative treatment, which is less prone to resistance development (Hillebrand et al. 2012; McGrath 2004; Rekanović et al. 2012). In addition, cymoxanil is regularly used in conjunction with other fungicides, which may also contribute to the lack of insensitivity observed. Insensitivity to cyazofamid has been found in other species of Phytophthora, including P. capsici (Jackson et al. 2012; Kousik and Keinath 2008). Although current $P$. infestans clonal lineages remain sensitive to cyazofamid, continued monitoring would be beneficial to anticipate changes in sensitivity.

Examination of the frequencies of clonal lineages over the past 5 years has indicated a displacement of the US-22 lineage (see USAblight.org). The number of isolates identified as US-23 has become more prevalent, while the number of isolates collected from all other lineages has decreased, and some have not been detected at all during the most recent years of this study. In addition, isolates of US-8 and US-11 were found only on the west coast in 2013, suggesting a different source of inoculum in the west for those outbreaks than in the eastern United States. Isolates of US-7 were detected in Florida in 2013 and were insensitive to mefenoxam (data not shown). This lineage was prevalent in the United States during the mid-1990s but has not been detected since then (Goodwin et al. 1998). The presence of US-7 may be the result of migration from outside the United States from movement of seed potato or tomato transplants; however, a phylogeographic study would be needed for confirmation.

Mefenoxam has been designated as having a high risk for resistance, and management practices have been developed to stall resistance development by rotation with alternative compounds with

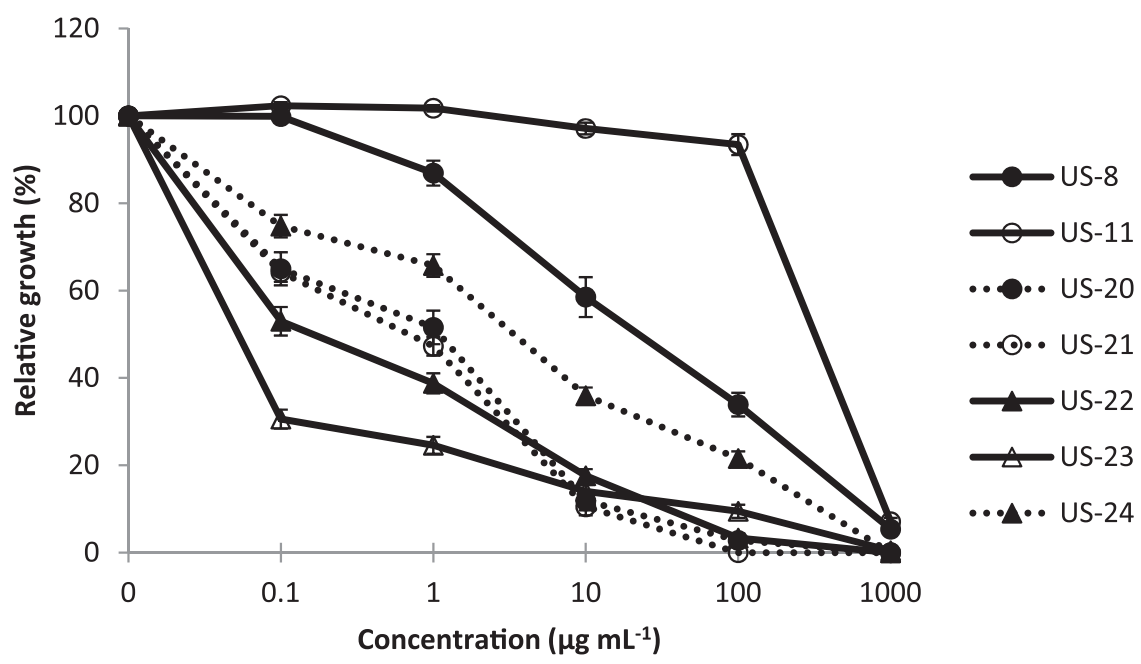

Fig. 3. Relative growth compared with nonamended control of seven clonal lineages of Phytophthora infestans to a range of concentrations of mefenoxam.

Table 1. Mean effective concentration at which $50 \%$ of growth was suppressed $\left(\mathrm{EC}_{50}\right)$ values for mefenoxam of U.S. clonal lineages of Phytophthora infestans collected from 2004 to 2012 in the US.

\begin{tabular}{llcrr}
\hline & & & \multicolumn{2}{c}{ Mefenoxam EC $_{\mathbf{5 0}}\left(\boldsymbol{\mu g} \mathbf{~ m l}^{-\mathbf{1}}\right)^{\mathbf{x}}$} \\
\cline { 3 - 5 } Clonal lineage $(\boldsymbol{n})^{\mathbf{y}}$ & \multicolumn{1}{c}{ Host } & Mating type & Mean $\pm \mathbf{S E}^{\mathbf{z}}$ & Minimum \\
\hline US-8 (7) & Potato & A2 & $51.40 \pm 16.22 \mathrm{~b}$ & 1.00 \\
US-11 (8) & Potato, tomato & A1 & $338.18 \pm 48.65 \mathrm{a}$ & 169.88 \\
US-20 (2) & Tomato & A2 & $0.91 \pm 0.39 \mathrm{~b}$ & 0.80 \\
US-21 (2) & Tomato & A2 & $0.66 \pm 0.27 \mathrm{~b}$ & 0.30 \\
US-22 (6) & Potato, tomato & A2 & $0.59 \pm 0.28 \mathrm{~b}$ & 1.03 \\
US-23 (13) & Potato, tomato & A1 & $0.38 \pm 0.25 \mathrm{~b}$ & 0.03 \\
US-24 (7) & Potato & A1 & $3.61 \pm 0.69 \mathrm{~b}$ & 0.01 \\
\hline
\end{tabular}

${ }^{x}$ Mefenoxam $\mathrm{EC}_{50}$ values are based on pooled data consisting of the number of isolates, two independent trials, and three replicates per trial.

y Data on clonal lineage, host, and mating type from Hu et al. (2012); $n$ indicates the number of individuals tested for each lineage. US-22 was the primary causal genotype during the 2009 late blight outbreaks in the eastern United States. The simple sequence repeat alleles for the US-8, US-22, US-23 and US-24 can be found in Danies et al. (2013).

${ }^{\mathrm{z}}$ Mean $\mathrm{EC}_{50}$ values followed by the same letter are not significantly different from each other according to Duncan's multiple range test. $\mathrm{SE}=$ standard error. 
different modes of actions (Kuck et al. 2012; Müller and Gisi 2012; Urech and Staub 1985). The recent discovery of the mefenoxaminsensitivity allele RPA190 in the RNA polymerase I of $P$. infestans could lead to a quick polymerase chain reaction method for identification of insensitive strains of $P$. infestans and reduce the labor-intensive in vitro screening for fungicide sensitivity on media (Randall et al. 2014). However, recent data indicate that the RPA190 allele may not be tightly linked to mefenoxam insensitivity $(H$. Judelson, personal communication); therefore, the usefulness of this mutation for tracking insensitive strains is unclear.
The sensitivity of the recently emerged lineages of $P$. infestans to most of the fungicides tested in this study, including mefenoxam, is promising. USAblight sampling revealed that the only consistently mefenoxam-insensitive lineages are US-8 and US-11. In this and previous studies (Hu et al. 2012), the US-23 isolates tested were mostly sensitive to mefenoxam. The continuation of good management practices by growers will help to reduce selection pressure and prolong the effectiveness of current fungicidal compounds. However, continued monitoring of $P$. infestans is essential in order to receive early warning of insensitivity in current lineages, emergence of new

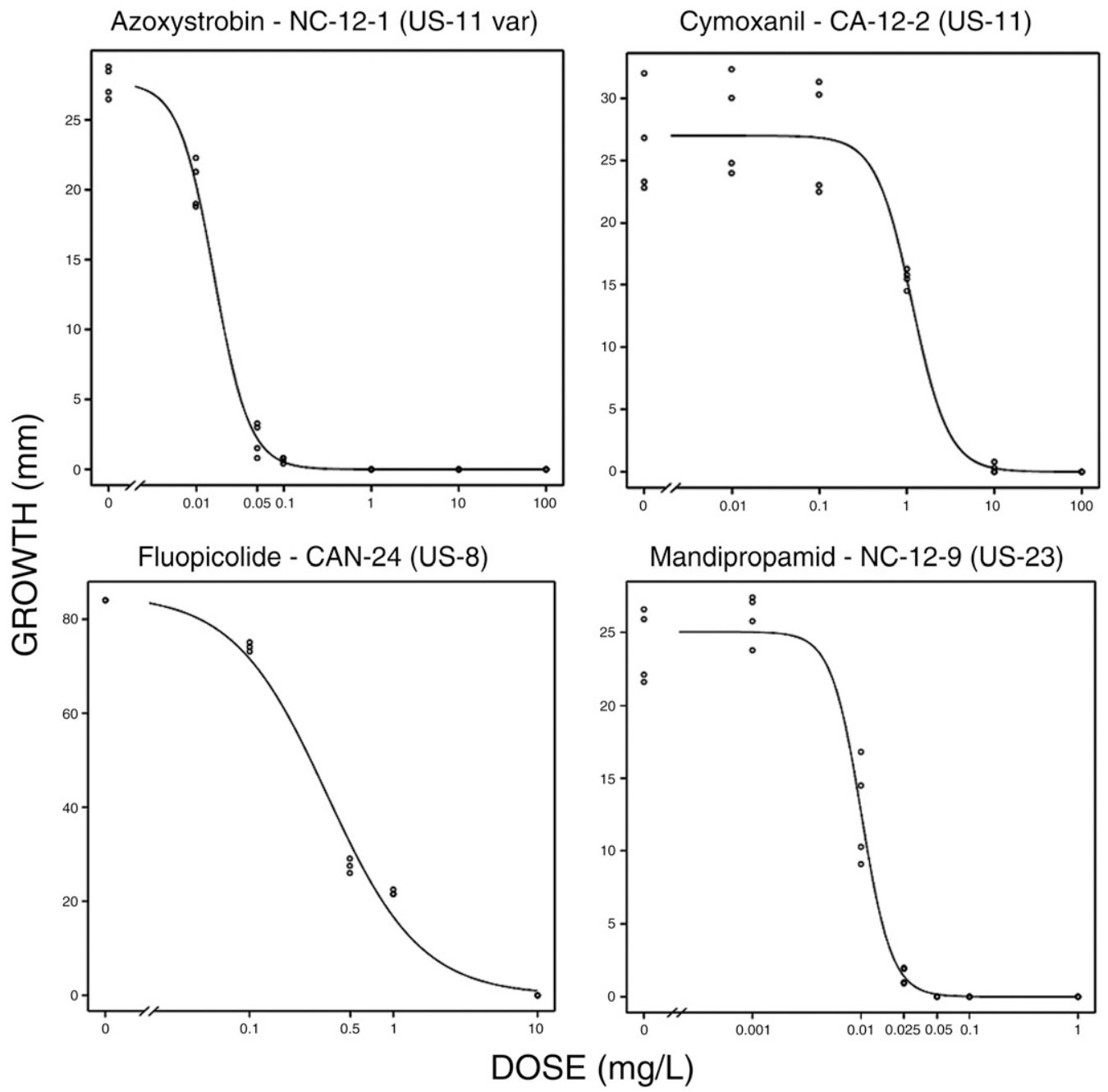

Fig. 4. Dose-response curves for growth of a typical US-8, US-11, US-20, US-21, US-22, US-23, and US-24 clonal lineage of Phytophthora infestans to azoxystrobin, cymoxanil, fluopicolide, and mandipropamid.

Table 2. Mean effective concentration at which $50 \%$ of growth was suppressed $\left(\mathrm{EC}_{50}\right)$ values for azoxystrobin, cymoxanil, fluopicolide, and mandipropamid of US clonal lineages of Phytophthora infestans collected from 2004 to 2012 in the US.

\begin{tabular}{lccll}
\hline & \multicolumn{4}{c}{ Mean \pm SE $\mathbf{E C}_{\mathbf{5 0}}\left(\boldsymbol{\mu} \mathbf{g ~ m l}^{\mathbf{- 1}}\right)^{\mathbf{z}}$} \\
\cline { 2 - 5 } Clonal lineage & Azoxystrobin & Cymoxanil & Fluopicolide & \multicolumn{1}{c}{ Mandipropamid } \\
\hline US-8 & $0.08 \pm 0.03(0.02-0.26) \mathrm{a}$ & $0.19 \pm 0.04(0.02-0.32) \mathrm{a}$ & $0.47 \pm 0.03(0.34-0.64) \mathrm{a}$ & $0.02 \pm 0.01(0.01-0.04) \mathrm{ab}$ \\
US-11 & $0.03 \pm 0.01(0.01-0.08) \mathrm{a}$ & $0.47 \pm 0.13(0.13-1.15) \mathrm{a}$ & $0.27 \pm 0.02(0.20-0.35) \mathrm{bcd}$ & $0.01 \pm 0.00(0.01-0.02) \mathrm{c}$ \\
US-20 & $0.05 \pm 0.02(0.04-0.07) \mathrm{a}$ & $0.10 \pm 0.07(0.02-0.17) \mathrm{a}$ & $0.37 \pm 0.04(0.34-0.44) \mathrm{ab}$ & $0.03 \pm 0.01(0.02-0.03) \mathrm{a}$ \\
US-21 & $0.07 \pm 0.00(0.07-0.07) \mathrm{a}$ & $0.09 \pm 0.03(0.07-0.12) \mathrm{a}$ & $0.18 \pm 0.07(0.19-0.26) \mathrm{cd}$ & $0.01 \pm 0.00(0.01-0.01) \mathrm{bc}$ \\
US-22 & $0.07 \pm 0.02(0.02-0.15) \mathrm{a}$ & $0.11 \pm 0.03(0.01-0.18) \mathrm{a}$ & $0.15 \pm 0.03(0.11-0.41) \mathrm{d}$ & $0.01 \pm 0.00(0.01-0.02) \mathrm{bc}$ \\
US-23 & $0.03 \pm 0.01(0.01-0.09) \mathrm{a}$ & $0.30 \pm 0.19(0.01-2.39) \mathrm{a}$ & $0.32 \pm 0.03(0.16-0.70) \mathrm{bc}$ & $0.01 \pm 0.00(0.00-0.02) \mathrm{c}$ \\
US-24 & $0.03 \pm 0.01(0.01-0.06) \mathrm{a}$ & $0.26 \pm 0.07(0.01-0.62) \mathrm{a}$ & $0.32 \pm 0.04(0.25-0.51) \mathrm{bc}$ & $0.01 \pm 0.00(0.01-0.02) \mathrm{bc}$ \\
\hline
\end{tabular}

${ }^{\mathrm{z}}$ Fungicide $\mathrm{EC}_{50}$ values (minimum-maximum) are based on pooled data from two independent trials and three replicates per trial. Mean $\mathrm{EC}_{50}$ values followed by the same letters are not significantly different according to Duncan's multiple range test. SE $=$ standard error. 
lineages, or reemergence of older lineages that may have different fungicide sensitivity profiles.

\section{Acknowledgments}

This project was funded by a USDA AFRI grant \# 2011-68004-30154. We thank DuPont, FMC, Syngenta, and Valent for supplying the fungicides for this study; E. Lassiter, C. Pearce, M. Harris, and NIFA interns S. Turner, M. Wyatt, and K. Bellingham for their laboratory assistance in conducting trials; and all the collaborators who provided samples to USAblight.org for further study in this work, including K. Everts, A. Gevens, B. Guino, D. Johnson, S. Johnson, W. Kirk, M. McGrath, P. Roberts, G. Secor, K. Seebold, and C. Smart.

\section{Literature Cited}

Anderson, P. K., Cunningham, A. A., Patel, N. G., Morales, F. J., Epstein, P. R., and Daszak, P. 2004. Emerging infectious diseases of plants: Pathogen pollution, climate change and agrotechnology drivers. Trends Ecol. Evol. 19:535-544.

Austin Bourke, P. M. 1964. Emergence of potato blight, 1843-46. Nature 203: 805-808.

Chen, C. H., Wang, T. C., Black, L., Sheu, Z. M., Perez, F., and Deahl, K. 2009. Phenotypic and Genotypic Changes in the Phytophthora infestans Population in Taiwan-1991 to 2006. J. Phytopathol. 157:248-255.

Childers, R., Danies, G., Meyers, K., Fei, Z., Small, I., and Fry, W. E. 2015. Acquired resistance to mefenoxam ion sensitive isolates of Phytophthora infestans. Phytopathology 105:342-349.

Cooke, D. E. L., Dodds, P. N., Cano, L. M., Raffaele, S., Bain, R. A., Cooke, L. R., Etherington, G. J., Deahl, K. L., Farrer, R. A., Gilroy, E. M., Goss, E. M., Grünwald, N. J., Hein, I., MacLean, D., McNicol, J. W., Randall, E., Oliva, R. F., Pel, M. A., Shaw, D. S., Squires, J. N., Taylor, M. C., Vleeshouwers, V. G. A. A., Birch, P. R. J., Lees, A. K., and Kamoun, S. 2012. Genome analyses of an aggressive and invasive lineage of the Irish potato famine pathogen. PLoS Pathog. 8:e1002940.

Daayf, F., and Platt, H. W. 2002. Variability in responses of US-8 and US-11 genotypes of potato and tomato isolates of Phytophthora infestans to commercial fungicides in vitro. Am. J. Potato Res. 79:433-441.

Daggett, S. S., Götz, E., and Therrien, C. D. 1993. Phenotypic changes in populations of Phytophthora infestans from Eastern Germany. Phytopathology 83:319-323.

Danies, G., Small, I. M., Myers, K., Childers, R., and Fry, W. E. 2013. Phenotypic characterization of recent clonal lineages of Phytophthora infestans in the United States. Plant Dis. 97:873-881.

Davidse, L. C., Looijen, D., Turkensteen, L. J., and Van Der Wal, D. 1981. Occurrence of metalaxyl-resistant strains of Phytophthora infestans in Dutch potato fields. Neth. J. Plant Pathol. 87:65-68.

Day, J. P., and Shattock, R. C. 1997. Aggressiveness and other factors relating to displacement of populations of Phytophthora infestans in England and Wales. Eur. J. Plant Pathol. 103:379-391.

Deahl, K. L., Inglis, D. A., and DeMuth, S. P. 1993. Testing for resistance to metalaxyl in Phytophthora infestans isolates from northwestern Washington. Am. Potato J. 70:779-795.

De Mendiburu, F. 2009. Una herramienta de analisis estadistico para la investigacion agricola. Thesis, Universidad Nacional de Ingenieria (UNI-PERU).

Dowley, L. J., and O'Sullivan, E. 1981. Metalaxyl resistant strains of Phytophthora infestans (Mont. de Bary) in Ireland. Potato Resist. 24:417-421.

Fry, W. E., Myers, K., Roberts, P., McGrath, M. T., Everts, K., Secor, G., Seaman, A., Gevens, A. J., Seebold, K., Jr., Zitter, T. A., Gugino, B. K., Snover-Clift, K., McLeod, A., Johnson, S. B., Wyenandt, A., Danies, G., Judelson, H., Grünwald, N. J., Small, I. M., Ristaino, J., and Smart, C. D. 2013. The 2009 late blight pandemic in the eastern United States-Causes and results. Plant Dis. 97:296-306.

Gavino, P. D., Smart, C. D., Sandrock, R. W., Miller, J. S., Hamm, P. B., Yun Lee, T., Davis, R. M., and Fry, W. E. 2000. Implications of sexual reproduction for Phytophthora infestans in the United States: Generation of an aggressive lineage. Plant Dis. 84:731-735.

Gisi, U., Lamberth, C., Mehl, A., and Seitz, T. 2012. Carbolic acid amide (CAA) fungicides. Pages 807-830 in: Modern Crop Protection Compounds. W. Krämer, ed. Wiley-VCH Verlag GmbH \& Co. KGaA, Weinheim.

Gisi, U., and Sierotzki, H. 2008. Fungicide modes of action and resistance in downy mildews. Eur. J. Plant Pathol. 122:157-167.

Gisi, U., Walder, F., Resheat-Eini, Z., Edel, D., and Sierotzki, H. 2011. Changes of genotype, sensitivity, and aggressiveness in Phytophthora infestans isolates collected in European countries in 1997, 2006 and 2007. J. Phytopathol. 159: 223-232.

Goodwin, S. B., Cohen, B. A., and Fry, W. E. 1994. Panglobal distribution of a single clonal lineage of the Irish potato famine fungus. Proc. Natl. Acad. Sci. USA 91:11591-11595.

Goodwin, S. B., Smart, C. D., Sandrock, R. W., Deahl, K. L., Punja, Z. K., and Fry, W. E. 1998. Genetic change within populations of Phytophthora infestans in the United States and Canada during 1994 to 1996: Role of migration and recombination. Phytopathology 88:939-949.

Grünwald, N. J., Flier, W. G., Sturbaum, A. K., Garay-Serrano, E., van den Bosch, T. B. M., Smart, C. D., Matuszak, J. M., Lozoya-Saldaña, H., Turkensteen, L. J., and Fry, W. E. 2001. Population structure of Phytophthora infestans in the Toluca valley region of central Mexico. Phytopathology 91:882-890.

Grünwald, N. J., Sturbaum, A. K., Montes, G. R., Serrano, E. G., Lozoya-Saldaña, H., and Fry, W. H. 2006. Selection for fungicide resistance within a growing season in field populations of Phytophthora infestans at the center of origin. Phytopathology 96:1397-1403.

Hillebrand, S., Zundel, J.-L., and Tietjen, K. 2012. Fungicides with unknown mode of action. Pages 865-885 in: Modern Crop Protection Compounds. W. Krämer, ed. Wiley-VCH Verlag GmbH \& Co. KGaA, Weinheim.

Hu, J., Hong, C., Stromberg, E. L., and Moorman, G. W. 2010. Mefenoxam sensitivity in Phytophthora cinnamomi isolates. Plant Dis. 94:39-44.

Hu, C.-H., Perez, F. G., Donahoo, R., McLeod, A., Myers, K., Ivors, K., Secor, G., Roberts, P. D., Deahl, K. L., Fry, W. E., and Ristaino, J. B. 2012. Recen genotypes of Phytophthora infestans in eastern United States reveal clonal populations and reappearance of mefenoxam sensitivity. Plant Dis. 96: $1323-1330$

Jackson, K. L., Yin, J., and Ji, P. 2012. Sensitivity of Phytophthora capsici on vegetable crops in Georgia to mandipropamid, dimethomorph, and cyazofamid. Plant Dis. 96:1337-1342.

Kato, M., Mizubuti, E. S., Goodwin, S. B., and Fry, W. E. 1997. Sensitivity to protectant fungicides and pathogenic fitness of clonal lineages of Phytophthora infestans in the United States. Phytopathology 87:973-978.

Kousik, C. S., and Keinath, A. P. 2008. First report of insensitivity to cyazofamid among isolates of Phytophthora capsici from the southeastern United States. Plant Dis. 92:979.

Kuck, K.-H., Leadbeater, A., and Gisi, U. 2012. FRAC mode of action classification and resistance risk of fungicides. Pages 539-557 in: Modern Crop Protection Compounds. W. Krämer, ed. Wiley-VCH Verlag GmbH \& Co. KGaA, Weinheim.

Lees, A. K., Stewart, J. A., Lynott, J. S., Carnegie, S. F., Campbell, H., and Roberts, A. M. I. 2012. The effect of a dominant Phytophthora infestans genotype (13_A2) in Great Britain on host resistance to foliar late blight in commercial potato cultivars. Potato Res. 55:125-134.

Li, Y., Cooke, D. E. L., Jacobsen, E., and van der Lee, T. 2013. Efficient multiplex simple sequence repeat genotyping of the oomycete plant pathogen Phytophthora infestans. J. Microbiol. Methods 92:316-322.

Martin, M. G., Cappellini, E., Samaniego, J. A., Zepeda, M. L., Campos, P. F., Seguin-Orlando, A., Wales, N., Orlando, L., Simon, Y. W. H., Dietrich, F. S., Mieczkowski, P. A., Heitman, J., Willerslev, E., Krogh, A., Ristaino, J. B., and Gilbert, M. T. P. 2013. Reconstructing genome evolution in historic samples of the Irish potato famine pathogen. Online journal. Nat. Commun. 4, Article number 2172

Matuszak, J. M., Fernandez-Elquezabal, J., Gu, W. K., Villarreal-Gonzalez, M., and Fry, W. E. 1994. Sensitivity of Phytophthora infestans populations to metalaxyl in Mexico: Distribution and dynamics. Plant Dis. 78:911-916.

McGrath, M. T. 2004. What are fungicides? Online publication. Plant Health Instruct.

Mitani, S., Araki, S., Yamaguchi, T., Takii, Y., Ohshima, T., and Matsu, N. 2001 Antifungal activity of the novel fungicide cyazofamid against Phytophthora infestans and other plant pathogenic fungi in vitro. Pestic. Biochem. Physiol. 70:92-99.

Müller, U., and Gisi, U. 2012. Newest aspects of nucleic acid synthesis inhibitors: Metalaxyl-M. Pages 901-908 in: Modern Crop Protection Compounds. W. Krämer, ed. Wiley-VCH Verlag GmbH \& Co. KGaA, Weinheim.

Nuninger, C., Watson, G., Leadbitter, N., and Ellgehausen, H. 1996. CGA329351: Introduction of the enantiomeric form of the fungicide metalaxyl. Pages 41-46 in: Proc. Br. Crop Prot. Conf. Pests Dis.

Ojiambo, P. S., Paul, P. A., and Holmes, G. J. 2010. A quantitative review of fungicide efficacy for managing downy mildew in cucurbits. Phytopathology 100:1066-1076.

Parra, G., and Ristaino, J. B. 1998. Insensitivity to Ridomil Gold (Mefenoxam) found among field isolates of Phytophthora capsici causing Phytophthora blight on Bell Pepper in North Carolina and New Jersey. Plant Dis. 82: 711

Pérez, W., Lara, J., and Forbes, G. A. 2009. Resistance to metalaxyl-M and cymoxanil in a dominant clonal lineage of Phytophthora infestans in Huánuco, Peru, an area of continuous potato production. Eur. J. Plant Pathol. 125:87-95.

Randall, E., Young, V., Sierotzki, H., Scalliet, G., Birch, P., Cooke, D. E. L., Csukai, M., and Whisson, S. C. 2014. Sequence diversity in the large subunit of RNA polymerase I contributes to Mefenoxam insensitivity in Phytophthora infestans. Mol. Plant Pathol. 15:664-676.

R Core Team. 2012. R: A Language and Environment for Statistical Computing. Vienna. http://www.R-project.org.

Rekanović, E., Potočnik, I., Milijašević-Marčić, S., Stepanović, M., Todorović, B. and Mihajlović, M. 2012. Toxicity of metalaxyl, azoxystrobin, dimethomorph, cymoxanil, zoxamide, and mancozeb to Phytophthora infestans isolates from Serbia. J. Environ. Sci. Health Part B. 47:403-409.

Ritz, C., and Streibig, J. C. 2005. Bioassay analysis using R. J. Stat. Softw. 12 $1-22$.

Rubin, A., Gotlieb, D., Gisi, U., and Cohen, Y. 2008. Mutagenesis of Phytophthora infestans for resistance against carboxylic acid amide and phenylamide fungicides. Plant Dis. 92:675-683. 
Sauter, H. 2012. Strobilurins and other complex III inhibitors. Pages 584-627 in: Modern Crop Protection Compounds. W. Krämer, ed. Wiley-VCH Verlag GmbH \& Co. KGaA, Weinheim.

Shattock, R. C. 1988. Studies on the inheritance of resistance to metalaxyl in Phytophthora infestans. Plant Pathol. 37:4-11.

Sujkowski, L. S., Fry, B. A., Power, R. J., Goodwin, S. B., Peever, T. L., Hamlen, R. A., and Fry, W. E. 1995. Sensitivities of Mexican isolates of Phytophthora infestans to chlorothalonil, cymoxanil, and metalaxyl. Plant Dis. 79:1117-1120.
Toquin, T., Latorse, M.-P., and Beffa, R. 2012. Fluopicolide: A new anti-oomycetes fungicide? Pages 831-838 in: Modern Crop Protection Compounds. W. Krämer, ed. Wiley-VCH Verlag GmbH \& Co. KGaA, Weinheim.

Turner, S. R. 2005. After the famine: Plant pathology, Phytophthora infestans, and the late blight of potatoes, 1845-1960. Hist. Stud. Phys. Biol. 35: 341-370

Urech, P. A., and Staub, T. 1985. The resistance strategy for acylalanine fungicides. EPPO Bull. 15:539-543. 